\title{
Dirsek kırıkları tedavisinde güncel yaklaşımlar
}

\section{Current concepts in fracture management of the elbow}

\author{
Jurjen Been, Denise Eygendaal \\ Amphia Hastanesi Ortopedi ve Travmatoloji Kliniği, Üst Ekstremite Bölümü, Breda, Hollanda \\ Department of Orthopedic Surgery, Upper Limb Unit, Amphia Hospital, Breda, the Netherlands
}

\section{RADIUS BAŞI KIRIKLARI \\ Giriş}

Radius başı kırıkları oldukça sıktır. Dirsek kırıklarının yaklaşık 1/3'ünü oluşturur. Bütün dirsek travmaları değerlendirildiğinde yaklaşık \%20'sinde radius başı ve/veya boyun kırı̆gı olduğu tahmin edilmektedir. ${ }^{[1,2]}$ Radius başı kırıkları radius boyun kırıklarından yedi kat fazla görülmektedir. ${ }^{[3]}$

Son çalışmalar radius başı kırıklarına sıklıkla 'ek yaralanmaların' eşlik ettiğini göstermiş̧tir. Lateral kollateral bağ (LKB) rüptürü, mediyal kollateral bağ (MKB) rüptürü, kıkırdak lezyonları ve ilişkili kırıklar özellikle Mason Tip 3 ve 4 kırıklarda oldukça sık görülmektedir. ${ }^{[2]}$ Ek yaralanmaların araştırılması acil serviste ayrıntılı bir özgeçmiş, dikkatli bir fizik tedavi ve uygun görüntüleme ile başlar.

MKB valgus güçlerine karşı ana stabilizatör olduğu için, eğer sağlamsa radius başı valgus stabilitesine herhangi bir katkıda bulunmaz. Ancak eğer MKB'de yırtık ve/veya koronoid çıkıntıda MKB'nin ulnar ayak izini içeren kırık varsa, ki standart radyografilerde belirlemek zor olabilir, radius başı dirseğin ikincil ana stabilizatörü olarak görev alır.

Radius başı kırıkları tarihsel olarak Mason sınıflamasına göre sınıflandırılır. ${ }^{[4]}$ Sıklıkla eşlik eden önemli lezyonlar olması nedeniyle, biz ilişkili travmatik dirsek lezyonlarını içeren Tip 4 sınıflamayı içinde bulunduran Johnston'ın genişletilmiş Mayo sınıflamasını (Tablo 1) kullanmaktayız. ${ }^{[5]}$

\section{RADIAL HEAD FRACTURES Introduction}

Radial head fractures are very common; they compromise of up to $1 / 3$ of all elbow fractures. In all elbow traumas it is estimated that in nearly $20 \%$ radial head and neck fractures occur. ${ }^{[1,2]}$ Radial head fractures occur seven times more than neck fractures. ${ }^{[3]}$

Recent studies revealed that radial head fractures are often accompanied by 'associated injuries'. Rupture of lateral collateral ligament ( $L C L)$, medial collateral ligament (MCL), chondral lesions, and associated fractures are seen quite often especially in Mason Type 3 and 4 fractures. ${ }^{[2]}$ Screening for associated injury starts at the emergency department with a thorough history, a careful physical examination, and proper imaging.

As the medial collateral ligament is the primary stabilizer to valgus forces, the radial head does not provide any valgus stability if the $M C L$ is intact. However, if there is a rupture of the MCL and/or a fracture of the coronoid process including the ulnar footprint of the MCL, which may be hard to identify on standard radiographs, the radial head is an essential secondary stabilizer of the elbow.

Radial head fractures are historically classified according to the Mason classification. ${ }^{[4]}$ Since there are often important associated lesions, we use the extended Mayo classification according to Johnston (Table 1) which includes a Type 4 injury representing associated traumatic elbow lesions. ${ }^{[5]}$

Table 1. Mason-Johnston classification of radial head fractures

\begin{tabular}{cl}
\hline Type & Description \\
\hline 1 & Non-displaced fracture \\
2 & Minimal displacement with angulation or impression \\
3 & Comminuted fracture with dislocation \\
4 & Radial head fracture with dislocation of elbow
\end{tabular}

- Illetişim adresi: Jurjen Been, Amphia Hospital, Molengracht 21,4118 CK Breda, the Netherlands Tel: 0031 - 76 - 5953378 e-posta: jbeen2@amphia.nl

- Geliş tarihi: 10 Ocak 2014 Kabul tarihi: 10 Ocak 2014 
Yakın zamanda Van Riet ve arkadaşları da yine ilişkili yaralanmalar üzerine odaklanmış bir sınıflama tanımladılar. ${ }^{[6]}$ Eğer standart radyografiler yaralanma ile ilgili yeterli bir sınıflama yapmaya imkan vermiyorsa, ek olarak dirseğin bilgisayarlı tomografisi (BT) çekilerek kırık parçalarının çıkık miktarları ve dirsekte eşlik eden yaralanmalar değerlendirilir. Radius başı kırıkları sıkIıkla standart grafilerde görülenden daha komplekstir ve radius başı kırı̆ıının çıkık miktarı standart grafilerde görülenden daha az ciddidir. ${ }^{[7]}$ Eşlik eden yaralanmalar normal klinik değerlendirme sırasında sıklıkla göz ardı edilir.

\section{Cerrahi endikasyonlar}

Mason Tip 1 kırıklar konservatif olarak tedavi edilebilir. Eklem aspirasyonu ya da alçı ile tespite gerek yoktur. ${ }^{[8,9]}$

İzole radius başı kırıklarının cerrahi tedavisi için endikasyonlar deplase (Tip 2 ve 3 ) kırıklar ve/veya pronasyon ve supinasyonda $(<70 \%)$ kısıtlılıktır. Tecrübemize göre, ilk muayene sırasında pronasyon ve supinasyonda var olan kısıtlılıklar cerrahi girişim yapılmadığı sürece takiplerde, iyileşme tamamlandığında ya da sonrasında azalmaz.

Minimal deplase Tip 2 kırıkların tedavisi tartışmalıdır; ideal tedavi yöntemini bulmak için daha ileri araştırmalar gerekmektedir.

Ek yaralanmaların eşlik ettiği Tip 4 kırıklarda tedavi kendine hastır ve daha sonra tartışılacaktır.

\section{Önemli noktalar ve sık yapılan hatalar}

- Radius başı kırıklarının redüksiyon ve tespiti artroskopik ya da açık olarak yapılabilir. Farklı vidalar kullanılarak aynı sonuçlar elde edilebilir. ${ }^{[10]}$ Ancak, önemli olan vidaları eklem yüzü olmayan bölgeye yerleştirmek ya da başsız vidalar kullanarak kıkırdağın altına gömmektir. Mutlaka dirseğin supinasyon ve pronasyona tam gelip gelmediği kontrol edilerek, vidaların proksimal ulnaya karşı sıkışmadığından emin olmak gerekir.

- Vida ucu mediyale taşmamalıdır, aksi halde ulnaya temas edip supinasyon/pronasyon kısıtlılığına neden olabilir.

- Radius boyun kırıklarının tedavisi ince profil plaklama ile yapılabilir. Temel amaç, bütün redüksiyonlarda olduğu gibi, erken harekete olanak tanıyan stabil, anatomiğe yakın tespittir. Ikeda ve arkadaşlarının yaptığı bir çalışmada, radius proksimalindeki bütün plakların implanta bağlı rahatsızlık vermesi nedeni ile çıkartılmaları gerektiği gösterilmiştir. ${ }^{[11]}$ Alternatif olarak, radius başını
Recently, a classification has been described by Van Riet et al. which also focus on associated injuries. ${ }^{[6]}$

If standard radiographs are not sufficient to give a proper classification of the injury, an additional computer tomography (CT) scan of the elbow is indicated to make a proper evaluation of the fracture, to assess the amount of dislocation of the fracture elements and associated injury of the elbow joint. A fracture of the radial head is often more complex, and the dislocation of the radial head fracture is often less severe than what is observed on a routine standard X-ray imaging. ${ }^{[7]}$ Associated injury is often underestimated during normal clinical evaluation.

\section{Indications for surgery}

Mason 1 fractures can be treated conservatively; there is no indication for aspiration of the joint or cast immobilization. ${ }^{[8,9]}$

Indications for surgery for isolated radial head fractures are displaced fractures (Type 2 and 3 ) and/or limited pronation-supination $(<70 \%)$ during physical examination. In our experience limited pronation-supination during initial evaluation will not improve during follow-up, recovery, and after healing of the fracture unless surgical intervention takes place.

Treatment of minimal displaced Type 2 fractures is somewhat controversial; future investigation is needed to determine optimal treatment.

Associated injuries / Type 4 fractures are treated on their own merit and will be discussed below.

\section{Pearls and pitfalls}

- Reduction and fixation of radial head fractures can be done arthroscopically or open. Different types of screws can be used with the same results ${ }^{[10]}$ however it is important to place the screws in the non-articulating portion or to use headless screws that can be buried beneath the articulating cartilage. Always check full supination and pronation for impingement of the screws against the proximal ulna.

- The screw tip should not protrude medially, as it will contact the ulna and interfere with supination/ pronation.

- Fixation of radial neck fractures can be done by plating, with a current trend to non-bulky plates. The main goal of all fixation is near-anatomically, stabile reduction which allows early mobilisation. A study by lkeda et al. shows that the plates in the proximal radius must almost always be removed due to hardware prominence. ${ }^{[11]}$ As an alternative, 
radius cismine tespit için çapraz vidalama kullanılabilir (Şekil 1). Bu yöntem teknik olarak daha zordur, ancak implant çıkartılması için yapılan ikinci cerrahiye gerek duyulmaz.

- Tip 3 kırıklarda redüksiyon ve stabil tespit zor, hatta bazen imkansız olabilir. Ring, üç ana parçadan daha çok parçalı olan radius başı kırıklarının tespitinin daha kötü sonuçlandığını göstermiştir. [12] Seçilmiş olgularda radius başı protezi bir seçenek olabilir. Her ne kadar implant tasarımında gelişmeler varsa da, radius başı protezi sonrası klinik sonuçlar değişkendir. ${ }^{[13-15]}$

- Antuna ve arkadaşlarının yaptığı bir çalışmada, radius başı eksizyonu sonrası iyi sonuçlar gösterilmiştir; ancak, bu tedavi yöntemi birçok risk içerir. Bunlar arasında, valgus instabilitesi, radiusun el bileğinde proksimalizasyonu ve LKB'de gerginlik kaybı sayılabilir. ${ }^{[16]}$

- Eğer kırık gerektiği gibi tespit edilemiyorsa radius başı eksizyonu bir seçenek olabilir. Her zaman dirsek ve ön kol stabilitesi kontrol edilmeli, eğer LKB, MKB ya da interosseöz bağda yetmezlik bulguları varsa, radius başı protezi uygulanmalıdır.

- Deplase, parçalı radius başı kırıklarını tedavi ederken her zaman radius başı protezini de içeren değişik tedavi seçenekleri hazır olmalıdır. crossing screws can be used to fix the radial head to the shaft (Fig. 1). This is technically more demanding, but prevents second surgery for hardware removal.

- In Type 3 fractures, reduction and stable fixation can be challenging and sometimes impossible. Ring showed that fixation of a radial head fractures with more than three major pieces is related to an inferior outcome. ${ }^{[12]}$ In selected cases, radial head replacement can be an option. Despite improvements in design, clinical results after radial head replacement are various. ${ }^{[13-15]}$

- A study by Antuna et al. shows good results from radial head excision but there are a lot of backsides to this treatment including valgus instability, proximalisation of the radius in the wrist joint, and lack of tension on LCL. ${ }^{16]}$

- If the fracture cannot be fixed adequately, the radial head can be excised as an alternative. Always check the stability of the elbow and forearm and perform a radial head replacement if there are signs of insufficiency of the LCL, the MCL or the interosseous membrane.

- When treating a displaced, comminuted radial head fracture, always have different kinds of treatment options available, including radial head replacement.

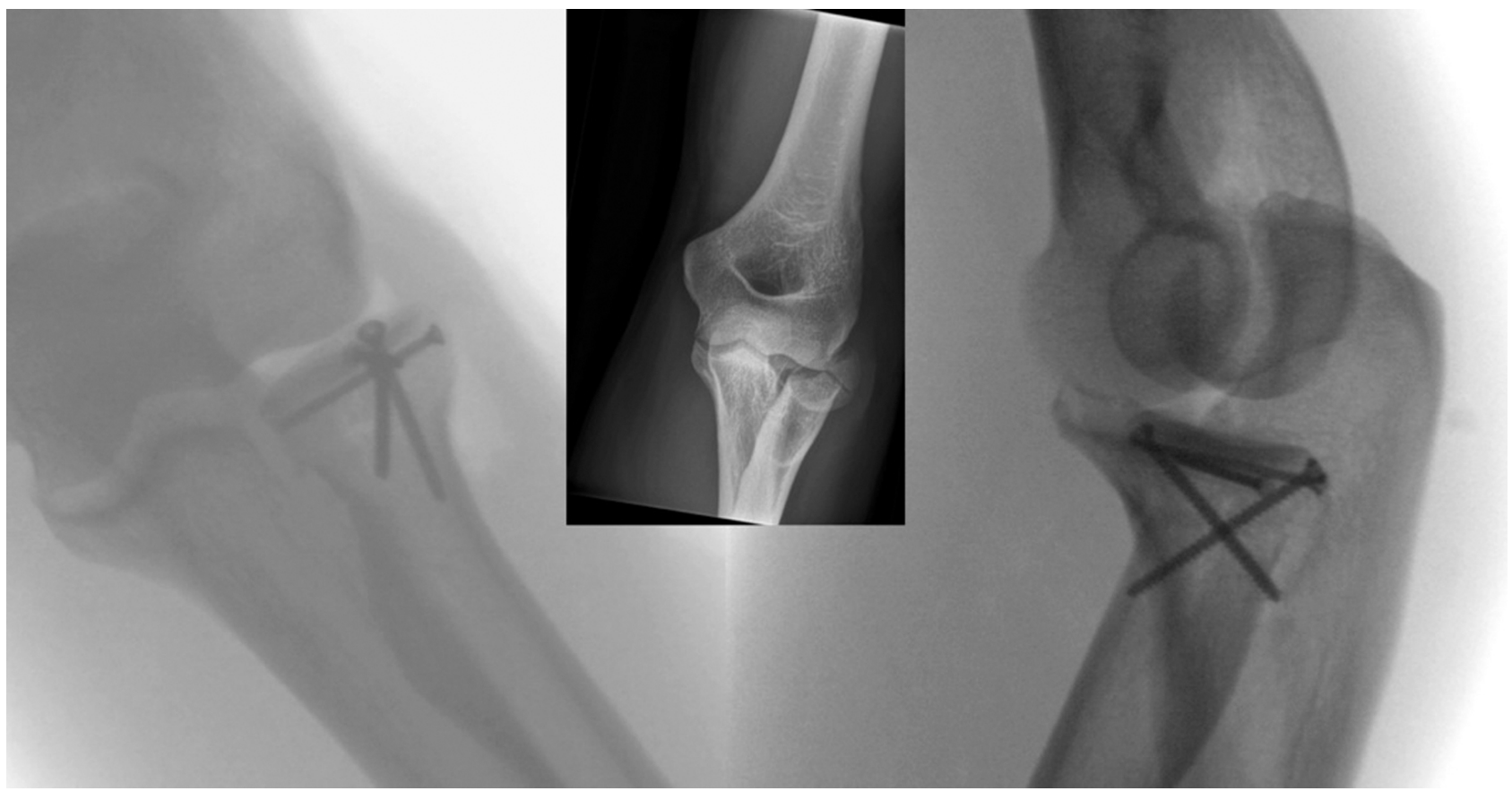

Şekil 1. Radius başı kırığının vida ile tespiti.

Figure 1. Screw fixation of a radial head fracture. 
- Radius başı cerrahisinde biz Kaplan aralığını kullanmayı tercih ediyoruz çünkü, bize göre, ekstansör karpi radyalis ile ekstansör dijitorum kommunis aralığını kullanan Kaplan aralığında, Kocher aralığına göre LKB kompleksinin hasar görmesi riski daha düşüktür. Anüler bağ uzunlamasına bölünür ve daha sonra anatomik olarak kapatabilmek için işaret sütürleri koyulur.

- Tedavinin amacı mümkün olduğunca erken dönemde fonksiyonel aktif eklem hareket açıklığına izin verecek stabil bir dirsek elde etmektir.

\section{Sonuçlar}

Tip 1 radius başı kırıklarının konservatif tedavisi sonrası uzun dönemde iyi sonuçlar beklenebilir. ${ }^{9,17,18]}$

Basit ve orta derecede deplase parsiyel radius başı kırığı (2-5mm arası deplasman) sık görülmeyen bir kırık şeklidir. ${ }^{[19]}$ Mümkün olan en iyi kanıtlar geriye dönük olgu serilerinden ve göreceli küçük kohort çaış̧malardan elde edilmiştir; ancak, bu çalışmalar kırık sınıflamaları, tedavi yöntemleri ve girişimleri, klinik, fonksiyonel ve radyolojik değerlendirme şekillerine ve takip sürelerine göre değişkenlikler göstermektedir. Sözü edilen çalışmalar III. ve IV. seviye oldukları için ${ }^{[20]}$, bu kırık tiplerinin cerrahi dışı ve cerrahi tedavileri için ancak $B / C$ seviyesinde önerilerde bulunulabilir. Bu parsiyel eklem içi kırıkların ideal tedavi yöntemlerini belirlemek için randomize, ileriye dönük ve/veya olgukontrol kohort çalışmalar ihtiyaç vardır. Sınırlı literatür ışığında, bu Tip 2 kırıklarda konservatif tedavinin sonuçları kötü olmasa da, cerrahi tedavinin daha iyi sonuç verdiği söylenebilir. ${ }^{[12,21]}$

Tip 3 radius başı kırıklarında, radius başı protezi içten tespite göre daha iyi sonuç vermektedir. ${ }^{[22]}$

Akut radius başı protezi sonrası hastaların \%90'ı dört yıllık takiplerde sonuçtan memnunlardır. Gecikmiş radius başı protezi sonrası takiplerde bu oran \%50'ye düşmektedir. ${ }^{[13]}$

\section{Komplikasyonlar}

Radyohumeral eklem dejenerasyonu her tür tedavi sonrası görülebilen en sık komplikasyondur. ${ }^{[9,16,23,24]}$ Ekstansiyon kaybı sıklıkla radius başı kırığı sonrası görülür. ${ }^{[2]}$ Deplase olmamış kırıklarda orta derecede deplase olmuş kırıklara göre daha az ekstansiyon kaybı riski vardır. ${ }^{[5,9]}$ Hareket genişliğinin tekrar kazanılması yaralanma sonrası uzun bir dönemde olur bu nedenle gelişme olduğu sürece konservatif tedaviye devam edilmelidir.

İkincil çıkık çok seyrektir ve eğer olursa erken dönemde görülür. Bu nedenle kırık sonrası ikinci haftada radyografiler tekrarlanmalıdır. Açık redüksiyon ve içten
- We use the Kaplan's interval between the extensor carpi radialis and extensor digitorum communis to approach the radial head, because in comparison to the Kocher's interval it is, in our opinion, less likely that the LCL complex is injured. Divide the annular ligament longitudinally and place stay sutures so that the ligament can be closed anatomically during closure.

- The goal of treatment is to achieve a stable elbow which allows a functional after treatment with active range of motion as soon as possible.

\section{Results}

Good long term results can be expected from conservative treatment of Type 1 radial head fractures. ${ }^{9,17,18]}$

The simple and moderately displaced partial radial head fracture (displacement, $2-5 \mathrm{~mm}$ ) is an uncommon fracture pattern. ${ }^{[19]}$ The best available evidence is limited to retrospective case series and relatively small cohort studies with differences in fracture classification, treatment techniques and approaches, methods of clinical, functional and radiographic evaluation, and durations of follow-up. As the series discussed below are limited to Level III and IV data ${ }^{[20]}$, Grade B/C recommendations exist for both non-operative and operative treatment of these fracture types. Randomized, prospective, and/or case-control cohorts are needed to elucidate the optimal treatment of partial articular fractures of the radial head. In the limited literature of these Type 2 fractures surgical treatment seems to give better results than conservative treatment, although the results of conservative treatment aren't that bad. ${ }^{[12,21]}$

In Type 3 fractures radial head replacement gives better results in comparison to internal fixation. ${ }^{[22]}$

In acute radial head replacement $90 \%$ of the patients are satisfied after nearly four years. This number decreases to $50 \%$ in delayed radial head replacement. ${ }^{[13]}$

\section{Complications}

Degeneration of the radiohumeral joint is the most common complication and can occur after all treatments. ${ }^{[9,16,23,24]}$ Loss of extension is often seen after a radial head fracture. ${ }^{[2]}$ Non-displaced fractures are less prone to an extension deficit than mildly displaced fractures. ${ }^{[5,9]}$ Range of motion can increase for a long time after injury and conservative treatment should be continued as long as there is improvement.

Secondary displacement is very rare and if occurs, it will happen early and should be anticipated by making radiographs in two weeks following the fracture. Some limitation of range of motion can be expected following 
tespit sonrası bir miktar hareket kıstlılığı beklenebilir; Tip 2 kırıklar için belirtilen hareket aralığı $10^{\circ}$ ekstansiyon, $130^{\circ}$ fleksiyondur. ${ }^{[12]}$ Seçilmiş olgularda, seçilen sert dirseği gevşetmek için ikinci cerrahiler uygulanabilir. Açık ve artroskopik girişimler sonrası sonuçlar birbirine yakındır. ${ }^{[25,26]}$

\section{PROKSIMAL ULNA VE KORONOID ÇIKINTI KIRIKLARI}

\section{Giriş}

Ulna kırıkları basit transvers ve oblikten kompleks çıkıklara kadar değişkenlik gösterebilir. Bu geniş çeşitlilik bütün kırıklar için uygun tek bir tedavinin olmadığı anlamına gelir. Bu nedenle, yaralanmanın patoanatomisini anlamak uygun tedavi şeklini seçmek için çok önemlidir. Bu bölümde, Mayo kırık sınıflamasını kullanarak doğru tedavi yöntemini seçmeniz için yardımcı olmaya çalışacağız.

Daha önce de tartışıldığı üzere, ana hedef erken harekete izin verecek stabil ve uyumlu bir eklem yüzü elde etmektir. Kompleks dirsek yaralanmalarında uyumlu ve stabil bir eklem elde etmek, hareket genişliğinden daha önemlidir.

Proksimal ulna, distal humerusla birlikte menteşe şeklinde bir eklem oluşturur. Ulnohumeral eklemin intrensek stabilitesinin önemli bir kısmı olekranonun posteriorda, koronoidin anteriorda 'buttress' yapmasına bağlı bu menteşe eklemden kaynaklanmaktadır. Eklemin bu şeklinin ve eklemdeki buttress'ın önemi, trokleanın ortasındaki kıkırdakta değişkenlik ve bazen kıkırdak yokluğu ile kanıtlanmaktadır.

Koronoid, trokleanın çıkmasını engelleyen en önemli stabilizatördür. Biyomekanik çalışmalar, dirsek eklemi ekstansiyona geldikçe tam fonksiyonel stabilite için, diğer eklem bileşenlerinin devamlılığına bakmaksızın, koronoidin en az \%50'sine ihtiyaç olduğunu göstermektedir. Radius başı, koronoide eklemi stabilize etmesi için yardım eder ve eğer radius başı sağlamsa koronoidin \%75'i çıkartılabilir. ${ }^{[27]} \mathrm{Bu}$ nedenle tüm kompleks dirsek kırık ve çıkıklarında, Mason Tip 2 ve 3 radius başı kırıklarında, radius başı tespit edilmeli ya da protez uygulanmalıdır.

\section{Cerrahi endikasyonlar}

Basit bir olekranon kırığı ile, olası ek yaralanmalar içeren proksimal ulnanın kompleks kırığı arasında ayrım yapmak önemlidir. Olekranon kırıklarında BT ancak beraberinde radius başı ve/veya koronoid kırı̆ı şüphesi varsa gereklidir. Mayo sınıflaması, doğru tedavi yöntemini seçmede yardımcıdır. ${ }^{[28]}$ open reduction and internal fixation (ORIF) of the radial head, with reported motion from an average of $10^{\circ}$ extension to $130^{\circ}$ of flexion in Type 2 radial head fractures. ${ }^{[12]}$ In selected cases secondary surgery as a surgical release of a stiff elbow is indicated. The results after open or arthroscopic procedures are comparable. ${ }^{[25,26]}$

\section{FRACTURES OF THE PROXIMAL ULNA AND THE CORONOID PROCESS}

\section{Introduction}

Fractures of the ulna vary from simple transverse and oblique patterns to complex dislocations. This wide variability makes no single treatment appropriate for all fractures. Therefore an understanding of the patho-anatomy of the injury pattern is essential for choosing the correct treatment. In this chapter we will help you choosing the right treatment using the Mayo fracture classification.

As with the previous discussed fractures, the primary objective remains as the restoration of a congruous joint surface with definitive stable fixation that allows early progression to motion. In complex elbow injuries, the restoration of a congruent joint and gaining stability is prevalent above range of motion.

The proximal ulna forms a joint with the distal humerus creating a hinge through its shape. An important part of the intrinsic stability of the ulnohumeral articulation lies within this shape and is formed by the olecranon as a buttress at the posterior side and the coronoid as a buttress on the anterior side. The importance of this shape and these buttresses in the joint is confirmed by the variability and sometimes lack of cartilage in the central part of the trochlea.

The coronoid acts as the most important articular stabilizer to prevent trochlear (sub)luxation. Biomechanical studies show that at least $50 \%$ of the coronoid is necessary to achieve functional stability as the joint nears extension regardless of the integrity of the other articular elements. The radial head helps the coronoid stabilizing the joint; if the radial head is intact $75 \%$ of the coronoid can be removed. ${ }^{[27]}$ It is for this reason that the radial head must be reconstructed or replaced for all complex elbow fractures and dislocations with Mason 2 or 3 radial head fractures.

\section{Indications for surgery}

It is important to distinguish between a simple fracture of the olecranon and a complex fracture of the proximal ulna with potentially associated injury. CT scan for olecranon fractures is only necessary if there is a suspicion of associated injury of the radial head and/or coronoid. Mayo classification helps in choosing the right treatment. ${ }^{[28]}$ 
Tip 1 kırıklar deplase olmamış olekranon kırıklarıdır ve alçı veya atel uygulaması ile tedavi edilebilirler. Alçı nötral rotasyonda uygulanmalıdır. Eklem hareketlerine 4-6 hafta sonra başlanır. illk altı hafta dirseğe $90^{\circ}$ 'den fazla fleksiyon verilmemesine ve dirence karşı aktif ekstansiyon yapmamaya dikkat edilmelidir.

Tip 2 kırıklar deplase, ancak dirseğin stabil olduğu kırıklardır; cerrahi tedavi gerektirir. Sadece parçalı ve belirgin oblikliği olmayan Tip 2A kırıklar gergi bandı ile tedavi edilebilir. Parçalı Tip 2B ve oblik Tip 2A kııklar, plak ve/veya destek yöntemlerle tespit edilmelidir.

Tip 3 kırıklar dirsek instabilitesi ile birliktedir ve cerrahi gerektirir. Çoğunda olekranon çok parçalıdır ve sıklıkla radius başı kırığı ile birliktedir. Anterior ya da posterior transolekranon kırıklı çıkık bulunabilir. Radius başının veya koronoidin anterior kırıkları posteriordan, kırık planından çalışarak tespit edilebilir. Koronoid K-teli, vida veya açılan deliklerden geçirilen sütürler ile tespit edilebilir. Tip 3 kırıklarda iyi bir osteosentez planlayabilmek için BT çekilmesi şarttır.

\section{Önemli noktalar ve sık yapılan hatalar}

- Olekranonun proksimali nispeten ince bir kortikal kabuktan oluşur; bu nedenle, tespitin kuvvetini arttırmak için, olekranon ucunun $35 \mathrm{~mm}$ distalinden başlayan kalın bölgenin kullanılması çok önemlidir.

- Sigmoid çentik nispeten çıplak bir alandır ve bu nedenle kırık parçalarındaki kayıpları ya da osteotomiyi tolere edebilir (Şekil 2).

- Gergi bandı K-telleri kırık tespitini güçlendirmek için anterior korteksi geçmelidir. Daha derine giderek ulnar korteksin geçilmemesine dikkat edilmelidir, aksi halde ulnar sinir zarar görebilir, radyal sıkışma oluşabilir ya da rotasyonel kısıtlııı gelişebilir (Şekil 3 ve 4).

- Gergi bandı K-telleri subkondral kemiğin hemen posterioruna yerleştirilir. Sık yapılan bir hata, K-tellerini fazla proksimale yerleştirerek giriş açısını çok düz yapmak ve K-tellerinin intramedüller gönderilmesine neden olmaktır.

- Kanal içi vidalar K-tellerine alternatif olarak kullanılabilir ve katı tespit için en az 80 mm uzunluğunda yol açılmış (tapped) olmalıdır.

- Radyohumeral eklemin ana stabilizatörü eklemin şekli olduğu için, amaç bu şekli tekrar kazanmaktır. Parçalı kırıklarda köprü plaklama, bütün parçaların vidalar ya da K-telleri ile redükte edilebildiği stabil kırıklarda ise kompresyon plaklama yöntemi kullanılabilir.
Type 1 fractures are olecranon fractures that are not displaced and can be treated non-operatively with application of a cast or splint. The cast should be applied in neutral rotation and range of motion can be started after 4-6 weeks. Elbow flexion $>90^{\circ}$ should be avoided during six weeks, and active extension against resistance should be avoided.

Type 2 fractures are displaced but the elbow remains stable, these fractures require surgical intervention. Only Type 2A non-comminuted fractures without significant obliquity can be treated by tension band fixation, Type $2 \mathrm{~B}$ comminuted fractures and oblique $2 \mathrm{~A}$ fractures must be fixated by a plate and/or supplement fixation.

Type 3 fractures are associated with elbow instability and require surgical intervention. The olecranon is in most cases comminuted and is often associated with a radial head fracture. There can be an anterior or posterior transolecranon fracture-dislocation. Anterior fractures of the radial head or coronoid can be fixed working from posterior through the fracture plane. The coronoid can be fixated with a K-wire, screw or by sutures through drillholes. In Type 3 fractures a CT scan is mandatory to perform a proper planning of the osteosynthesis.

\section{Pearls and pitfalls}

- The proximal part of the olecranon consists of a relatively thin dorsal cortical shell; therefore fixation in the thicker part of the olecranon, which starts approximately $35 \mathrm{~mm}$ distal to the tip, is essential to maximize the rigidity of the fixation.

- The sigmoid notch is a relative bare area and is therefore forgiving for missing fracture parts or osteotomy (Fig. 2).

- Tension band K-wires should just penetrate the anterior cortex to give the fracture rigidity. Deeper penetration of the ulnar cortex should be avoided to prevent damage to the ulnar nerve, radial impingement and rotational deficits (Fig. 3 and 4).

- Tension band K-wires are placed just posterior to the subchondral bone. A common error is introducing the K-wires too proximal, making the angle of introduction too flat and increasing the risk of intramedullary placement of the K-wires.

- Intramedullary screws can be used as an alternative for K-wires and should be at least $80 \mathrm{~mm}$ tapped to achieve rigid fixation.

- Since the main stabilizer of the radiohumeral joint is its shape, the goal of treatment is to restore this shape by using a bridging plate in comminuted fractures or a compression plate when all the fragments can be reduced stable using screws and/or K-wires. 


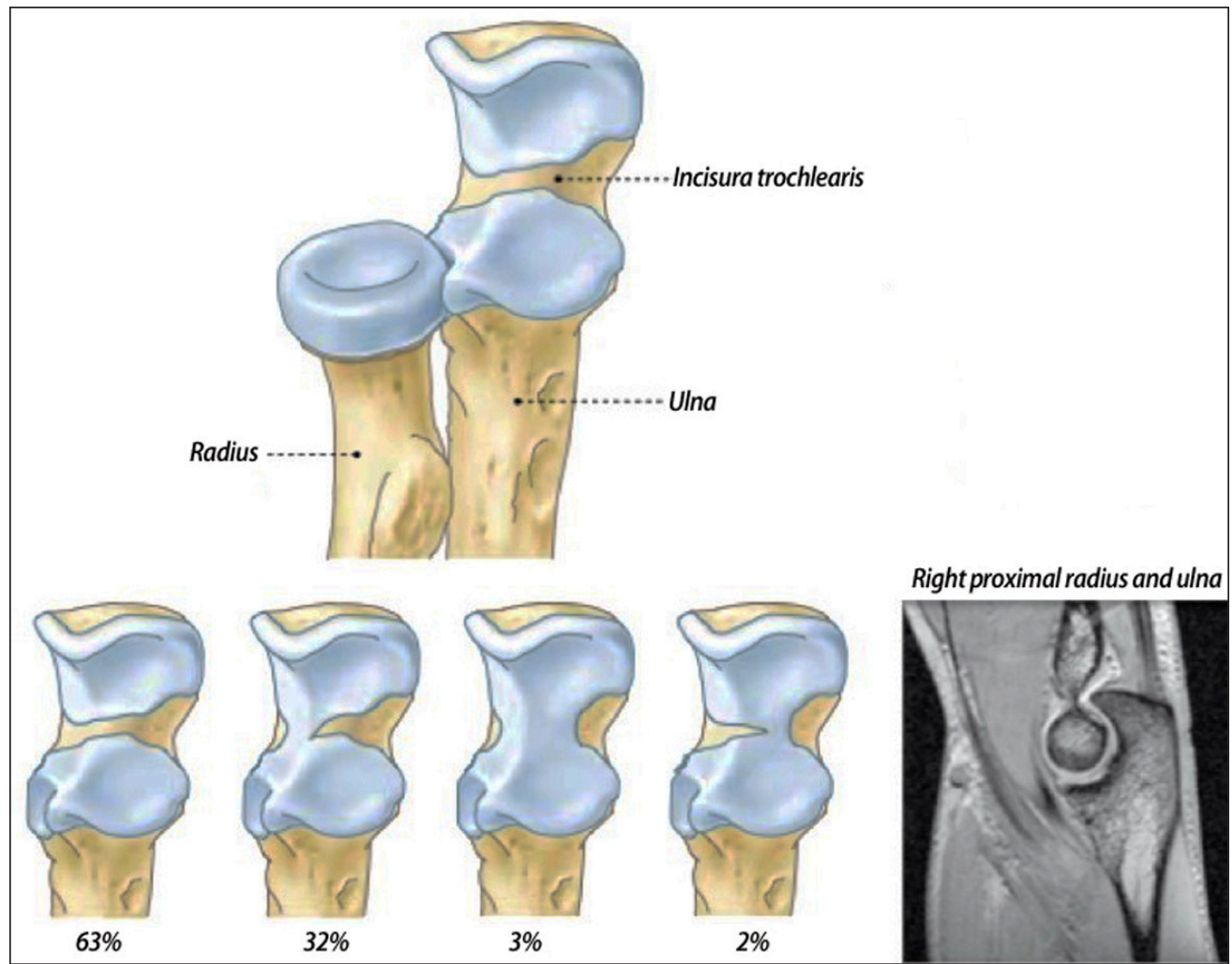

Şekil 2. Hiyalin kıkırdağın proksimal ulnada dağılımı çeşitlidir ve manyetik rezonans görüntülemede ulnanın osteokondral hasarı ile karıştırılabilir.

Figure 2. The hyaline cartilage distribution of the proximal ulna varies and is often misinterpreted as osteochondral damage of the ulna on magnetic resonance imaging.
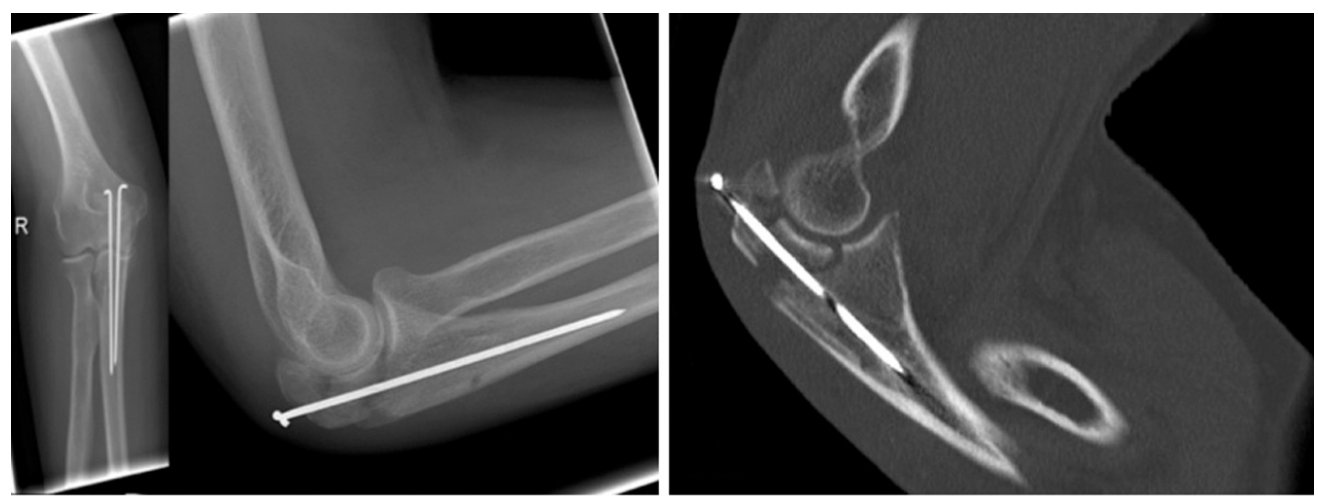

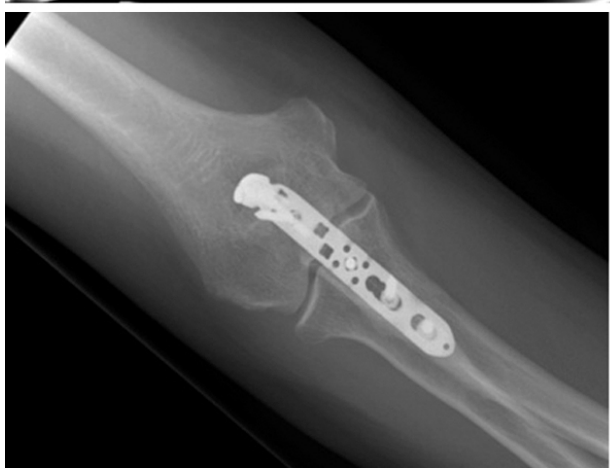

Şekil 3. Ön korteksi geçmeyen K-tellerinde rijidite kaybı ve plak ile yeniden tespiti.

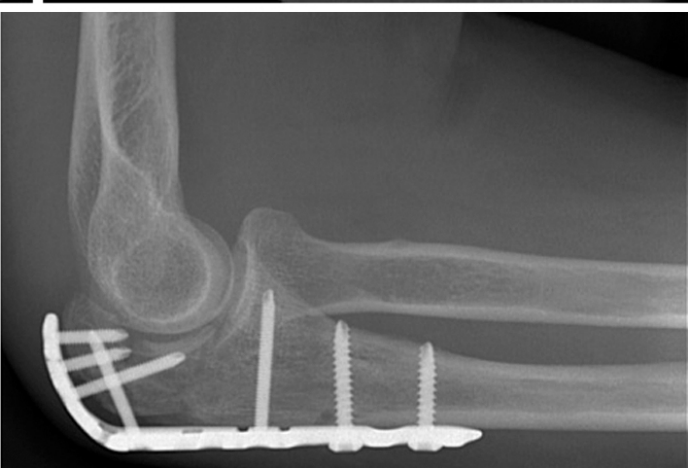

Figure 3. Lack of rigidity in K-wires not penetrating the anterior cortex and refixation using a plate. 


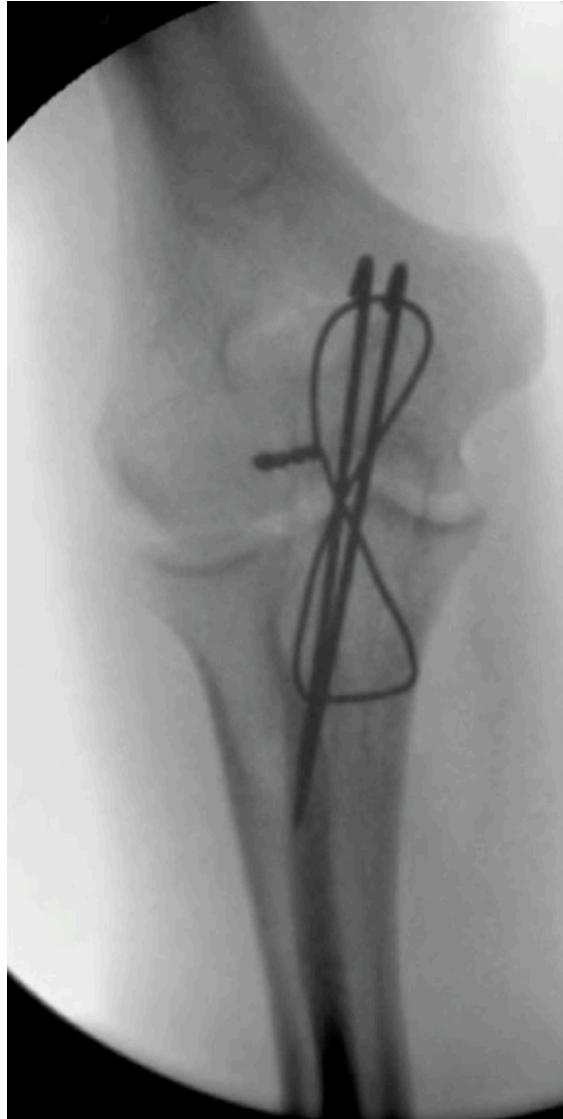

Şekil 4. Proksimal radiusda K-tellerinin protrüzyonuna bağlı rotasyonel defisit.
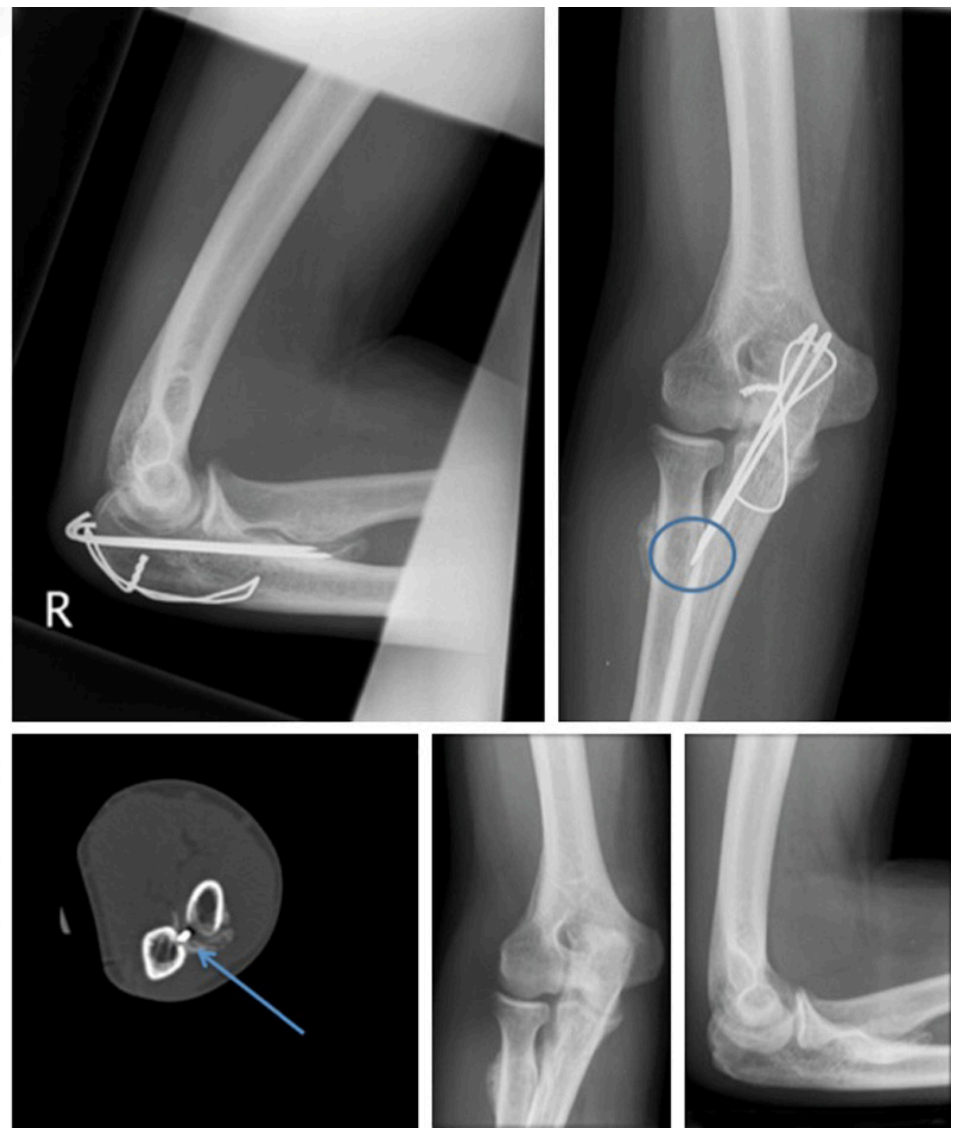

Figure 4. Protrusion of K-wires in the proximal radius causing a rotational deficit.
- Çok parçalı kırık alanlarında, ek olarak küçük vidalar veya $\mathrm{K}$-telleri kullanılabilir.

- Koronoid ayrı bir parça ise bir vidayla tespit etmek gerekir, aksi takdirde instabiliteye bağlı olarak yapı bozulur (Şekil 5).

- Olekranon ucundan koronoid tabanına gönderilecek bir vida stabiliteyi arttırır.

- Kırık stabilitesinden ve implanta bağlı sıkışma olmadığından emin olmak için, fleksiyonekstansiyon ve pronasyon-supinasyon hareket açıklıklarının tam olduğu kontrol edilmelidir.

- Kırıklı çıkık ile Monteggia kırığını ayırt edebilmek için, proksimal radyoulnar eklem değerlendirilir. Kırıklı çıkıkta proksimal radyoulnar eklem sağlamdır.

- Triseps insersiyosu, olekranon proksimalinin \%88'ini kaplar. Bu geniş ve güçlü yapışma, trisepsin hasarlanmadığı durumlarda anatomik plak yerleştirilebilmek için trisepsi sıyırmamıza olanak tanır. ${ }^{[29]}$
- Additional small screws or K-wires can be used in a comminuted fracture area.

- Fixate the coronoid with a screw when it is a separate fragment; otherwise the construct will fail due to instability (Fig. 5).

- The placement of a screw from the olecranon tip to the coronoid base increases fixation stability.

- Ensure full range of motion in flexion-extension and pronation-supination to check fracture instability and hardware impingement.

- To differentiate between a fracture-dislocation and a Monteggia fracture, assess the proximal radio-ulnar joint. The proximal radio-ulnar joint is intact in a fracture-dislocation.

- $88 \%$ of the width of the proximal olecranon is covered by the attachment of the triceps muscle, making it a strong enough structure to be splitted atits insertion point for anatomical contouring of the plate in an injury that did not damage the triceps. ${ }^{[29]}$ 


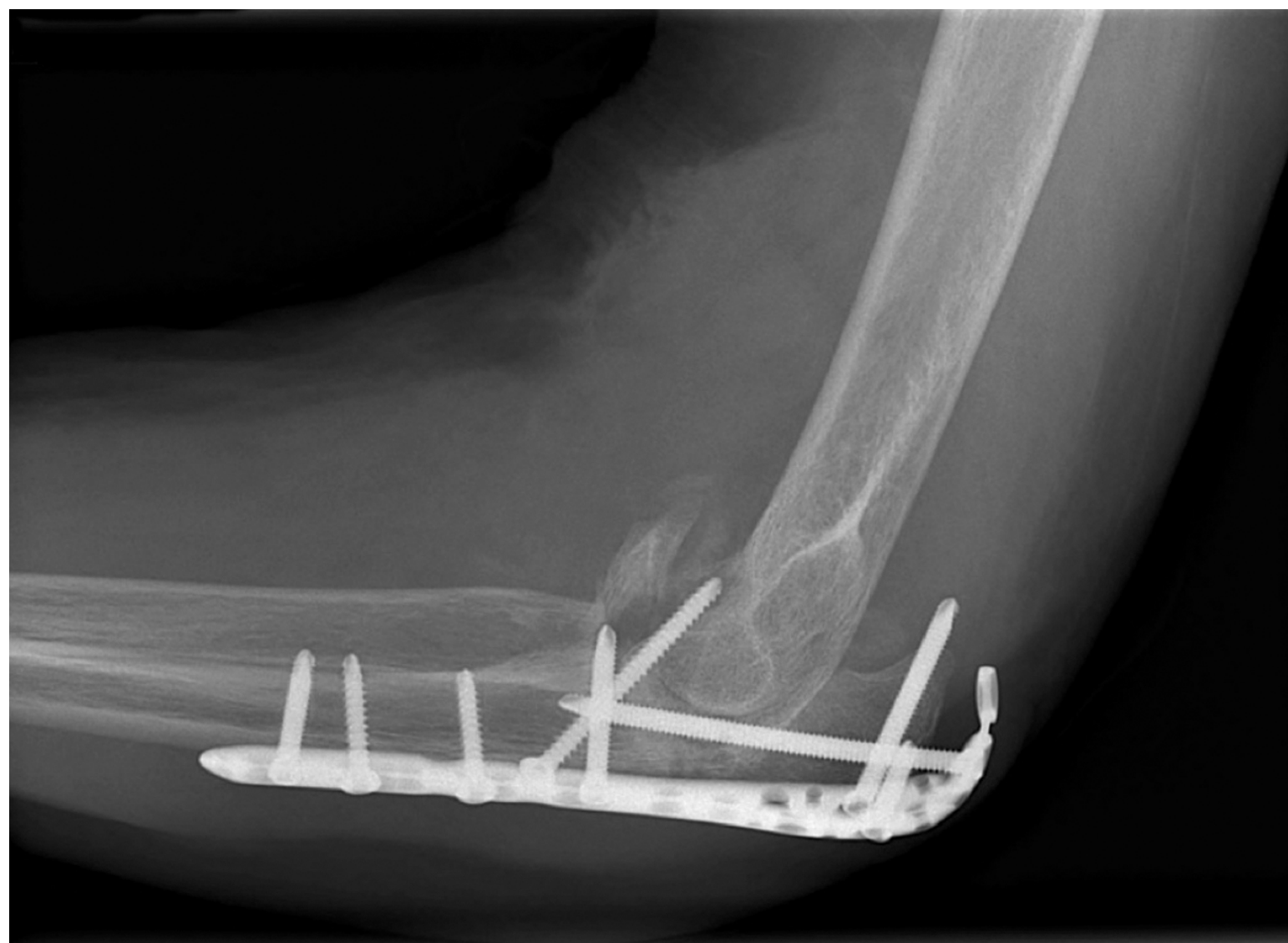

Şekil 5. Koronoid parçanın yeterince tespit edilmemesine bağlı gereç yetmezliği ve instabiliteye bağı çıkık.
Figure 5. Not adequately fixating the coronoid fragment made the construct fail and dislocate due to instability.

\section{Sonuçlar}

Alçı ya da atel gibi cerrahi dışı bir tedavi yöntemi ile tedavi edilmiş Tip 1 kırıklarda oluşan sertlik ve fonksiyonel olmayan hareket genişliği, uzamış immobilizasyona bağlıdır. ${ }^{[30]}$

Tip 2 olekranon kırıklarının gergi bandı ya da plak ile tespiti mükemmel sonuçlar verir. Tedavide önemli olan nokta, hangi kırığın gergi bandı ile tedavi edilebileceğini, hangisinin edilemeyeceğini bilmektir. ${ }^{[31-35]}$

Ring ve arkadaşları, transolekranon kırıklı çıkığı olan 13 hastada 25 aylık takiplerinde \%88 iyi ve mükemmel sonuç bildirmiştir. ${ }^{[36]}$ Lindenhovius ve arkadaşlarının daha uzun takipli (ortalama 18 yıl) 20 hastasında \%85 iyi ve mükemmel sonuç bildirilmiştir. Ancak, hastaların \%70'inde post travmatik osteoartrit görülmüştür. ${ }^{[37]}$

Proksimal ulna kırıkları sonrası ortalama ön kol rotasyonu $75^{\circ}$ pronasyon ve $70^{\circ}$ supinasyon iken, distal humerus kırıkları sonrası bu değerler $80^{\circ}$ pronasyon ve $75^{\circ}$ supinasyondur. ${ }^{[38,39]}$

\section{Results}

Stiffness and a non-functional arc of motion are being described as a result of the prolonged immobilisation in Type 1 fractures treated non-operatively with application of a cast or splint. ${ }^{[30]}$

Treatment of Type 2 olecranon fractures with tension band wiring or plate fixation gives excellent results. The most important value in the treatment is to know which fracture can be treated with tension band wiring and which can not. ${ }^{[31-35]}$

Ring et al. observed $88 \%$ good or excellent results in 13 patients treated for transolecranon fracturedislocation at an average follow-up of 25 months. ${ }^{[36]}$ Lindenhovius et al. had a longer follow-up (average 18 years) of 20 transolecranon fracture-dislocations with $85 \%$ good or excellent results. However, post-traumatic osteoarthritis was $70 \% .{ }^{[37]}$

The average forearm rotation arc after proximal ulnar fractures was $75^{\circ}$ of pronation and $70^{\circ}$ of supination compared to $80^{\circ}$ of pronation and $75^{\circ}$ of supination after a distal humeral fracture. ${ }^{[38,39]}$ 


\section{Komplikasyonlar}

Önemli komplikasyonlar arasında post-travmatik artrit, ilk travmaya ikincil ya da iyatrojenik instabilite, ulnar nöropati ve nörit, kısıtlı hareket ve heterotopik ossifikasyon, derin enfeksiyon ve kaynamama sayılabilir.

Literatürde en sık komplikasyon olarak implanta bağlı komplikasyonlar görülmektedir. Özellikle gergi bandı ya da K-telleri varsa, sıklıkla implant çıkartılmasına gerek duyulmaktadır. ${ }^{[30,33]}$ Romero ve arkadaşları, ortalama 8,5 ay takipli 46 hastalık gruplarında, hastaların \%70'inden daha çoğunda gergi bandını çıkartmak durumunda kalmışlardır. ${ }^{[30]}$ Plak tespiti daha az semptomatik implant rahatsızlığına neden olmaktadır ve implant çıkartılma oranı \%20'dir. ${ }^{[34,35]}$ İmplantların subkutan yerleşimi bu problemi neredeyse çözümsüz hale getirmektedir.

Özellikle ekstansiyonu içeren hareket kaybı tipik olarak $10-15^{\circ}$ 'dir ve oldukça sık görülür. ${ }^{[40]} 30^{\circ}$ 'den fazla kayıpla birlikte görülen fonksiyon kısıtlılığı daha seyrektir ve genelde kırıklı çıkıklara, yüksek enerjili yaralanmalara, eklem çevresinde şişme ve uzun süreli immobilizasyona bağlı görülür. ${ }^{[41,42]}$

Heterotopik ossifikasyon yaklaşık olarak kırıkların \%13'ünde görülür ve radius başı çıkıklarına, kompleks yaralanmalara ve kafa travmalarına bağlıdır. ${ }^{[31,33]}$

Ulnar nöropati hastaların \%2-10'unda görülmektedir. ${ }^{[30,31,43-45]}$

Kıkırdak yüzeydeki değişiklikler ilk yaralanmanın şiddeti ve redüksiyon kalitesi ile orantılıdır. ${ }^{[46]}$

\section{KORKUNÇ ÜÇLÜ}

'Korkunç üçlü' diye tabir edilen dirseğin kırıklı çıkık yaralanmasında, radius başı kırığı, koronoid kırığı ve özellikle LKB'yi içeren dirsek stabilizatör bağlarının yaralanması yer alır (Şekil 6).

Bu yaralanmada standart cerrahi, lateral yaklaşımdır. Bunun nedeni, MKB'nin ulnohumeral eklem redükte edildiğinde kendiliğinden iyileştiğinin biliniyor olmasıdır. MKB onarımı ancak koronoid ve radius başı kırığı tespit edilip LKB onarıldıktan sonra instabilite devam ediyorsa yapılır.

\section{Önemli noktalar ve sık yapılan hatalar}

- Illk olarak koronoid kırı̆ıı tespit edilir. Küçük parçalar, ulnada açılan deliklerden 'fiber wire' sütür geçirilerek tespit edilebilir. Daha büyük parçalar, vidalar ile redükte edilip tespit edilebilir. Radius başı tespiti ve LKB onarımı sonrası dirsek stabilse, küçük parçalar tespit edilmeden bırakılabilir.

\section{Complications}

Significant complications include post-traumatic arthritis, instability secondary to the initial or iatrogenic trauma, ulnar neuropathy and neuritis, restricted motion and heterotopic ossification, deep infection and non-union.

Hardware-related complications dominate the literature as the most frequent. Hardware removal is often needed especially with tension bands and K-wires. ${ }^{[30,33]}$ As described by Romero et al., at a median follow-up of 8,5 months, more than $70 \%$ of the tension bands were removed in a group of 46 patients. ${ }^{[30]}$ Plate fixation leads to less symptomatic hardware but also up to $20 \%$ of hardware removal. ${ }^{[34,35]}$ The subcutaneous placement of the hardware seems to make this problem almost unavoidable.

Motion loss, particularly in extension, is common and is typically $10-15^{\circ} .{ }^{[40]}$ Functional impairment with loss of more than $30^{\circ}$ is less common and occurs more often with fracture-dislocation, complex high-energy injuries, swelling around the joint, and a period of immobilization. ${ }^{[41,42]}$

Heterotopic ossification is seen in approximately $13 \%$ of the fractures and seems related to radial head dislocations, complex fracture types, and closed head injuries. ${ }^{[31,33]}$

Ulnar neuropathy has been reported in $2-10 \%$ of the patients. ${ }^{[30,31,43-45]}$

Articular surface changes correlate with the severity of the initial injury as well as with the quality of the reduction. ${ }^{[46]}$

\section{TERRIBLE TRIAD}

Terrible triad is a fracture-dislocation of the elbow that involves a fracture of the radial head, a fracture of the coronoid and injury of the ligamentous stabilizers of the elbow, especially the LCL (Fig. 6).

The standard approach in surgical treatment of this injury is a lateral approach. It relies on the knowledge that the MCL tends to heal without surgery if the ulnohumeral joint is reduced. Repair is only necessary if medial instability persists after fixation of the coronoid, repair of the lateral ulnar collateral ligament and treatment of the radial head injury.

\section{Pearls and pitfalls}

- First, the coronoid fracture is treated; small fragments can be fixed by placing a locked loop around the fragment with fiber wire and then passing each of the sutures through drill holes in the ulna. Larger fragments can be reduced and 


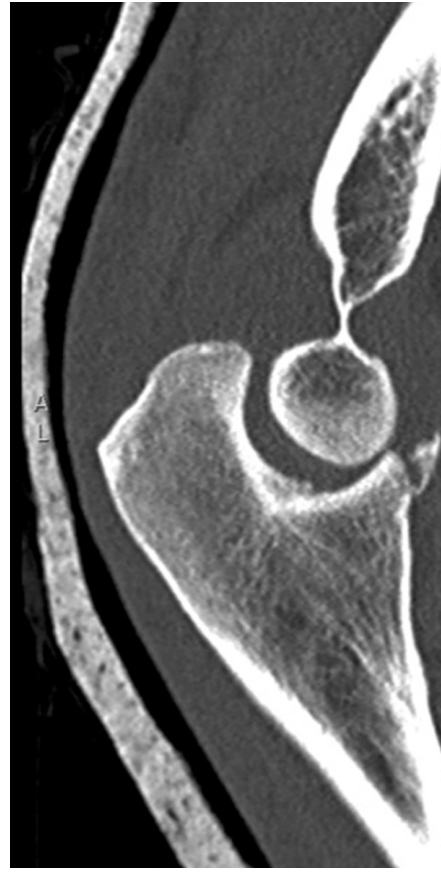

Şekil 6. Korkunç (ölümcül) üçlü.

- İkinci sırada radius başı onarılır. Ana hedef valgus stresine dayanacak anterior 'buttress'ı sağlamaktır. Radius başı daha önceden tartışıldığı gibi açık redüksiyon ve içten tespit veya protez ile tedavi edilebilir.

- Daha sonra LKB lateral kondildeki dirsek rotasyon merkezi olan yapışma yerine (en sık yaralandığı yer) tespit edilir. Kemiğe açılan delikler aracılığıyla ya da rotasyon merkezinin hemen proksimaline yerleştirilen bir sütür ankor ile bağ onarımı yapılır. LKB kompleksi tespit edilirken ön kol $45^{\circ}$ fleksiyon ve tam pronasyonda tutulur. Daha sonra ekstansör tendon kompleksi (ekstansör communis) kapatılır.

- Dirsek fizik muayene ve floroskopi ile stabilite yönünden değerlendirilir. Eğer valgus yönünde instabilite varsa, mediyal yaklaşımla MKB onarımı yapılabilir. Bütün kemik ve yumuşak doku stabilizatörlerinin onarılmasına karşın instabilitesi devam eden seçilmiş olgularda, dinamik eksternal fiksatör yerleştirilmesi endikasyonu vardır.

\section{DISTAL HUMERUS KIRIKLARI}

\section{Giriş}

Distal humerus kırıkları, erkeklerde 12-19 yaş arası, kadınlarda 80 yaş sonrası artış gösterir; ${ }^{[47]}$ bütün dirsek kırıklarının yaklaşık \%30'unu oluşturmaktadır. ${ }^{[48]}$

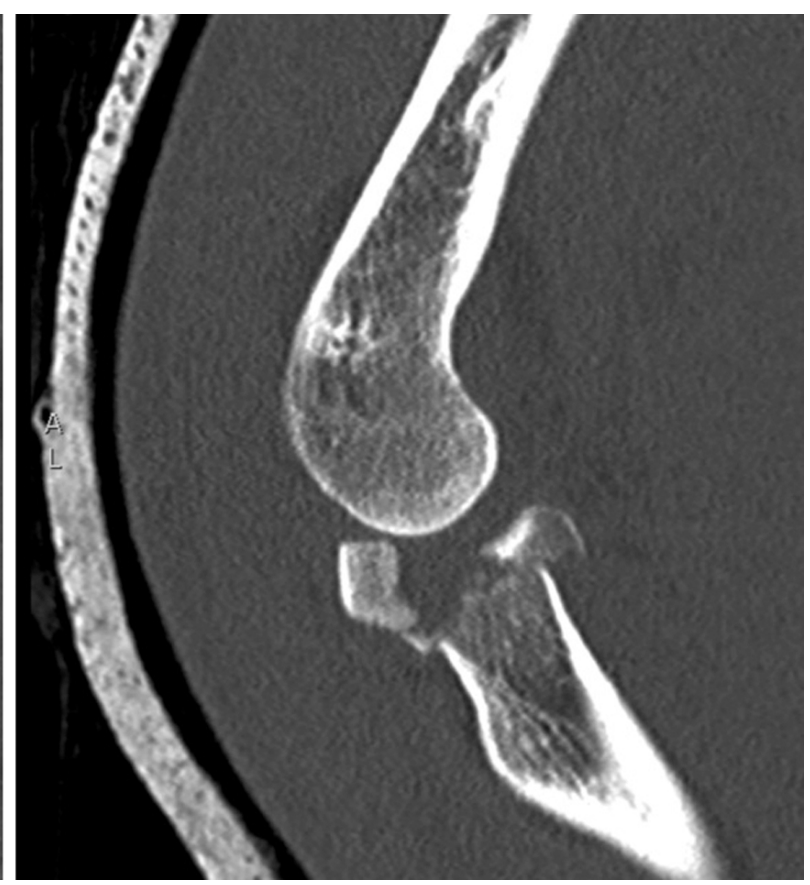

Figure 6. Terrible triad.

fixed by screws; small fragments can be left untreated if the elbow is stable after the repair of the radial head and the $\mathrm{LCL}$.

- Secondly, the radial head is addressed. The primary goal is to provide a stable anterior buttress to resist valgus stress. The radial head can be treated as discussed before by ORIF or radial head replacement.

- The LCL is then repaired back to the lateral condyle at the centre of rotation of the elbow where it's most commonly injured. The ligament is repaired through transosseous drill holes or with an anchor placed just proximal to the center of rotation. The forearm is held in $45^{\circ}$ of flexion and in full pronation, while the LCL complex is secured. The common extensor tendons are then closed.

- Assess the elbow for stability by physical examination and fluoroscopy. If the elbow shows instability in valgus direction, repair of the MCL can be done through a medial approach. In selected cases with persistent instability despite anatomic repair of all bony and soft tissue stabilizers, the placement of a dynamic external fixator is indicated.

\section{FRACTURES OF THE DISTAL HUMERUS}

\section{Introduction}

Peaks of incidence of distal humerus fractures can be seen in males with 12-19 years of age and females 80 


\section{Cerrahi endikasyonlar}

Davies, kolay uygulanabilir bir sınıflama yapmıştır. Kırıklar, eklem dışı, kısmen eklem içi ve tamamen eklem içi olmak üzere üçe ayrılır (Şekil 7). ${ }^{[49]}$ Kompleks kırıkları sınıflamak ve parça sayısı ile oryantasyonu sağlamak için BT çekilebilir.

\section{Önemli noktalar ve sık yapılan hatalar}

- Sıklıkla posterior yaklaşım kullanılır. Kırık tipine göre posterior triseps ayırıcı ya da olekranon osteotomisi yöntemi tercih edilebilir (Şekil 7).

- Ulnar sinir her zaman bulunup korunmalıdır, genelde transpozisyona gerek kalmaz.

- Kırık daha proksimale uzandığında, radyal sinir de ameliyat sırasında bulunup korunmalıdır.

- Radyal sinir, posterior humerus korteksini lateral epikondilin $10 \mathrm{~cm}$ proksimalinde çaprazlar. years or older. ${ }^{[47]}$ Distal humerus fractures account for approximately $30 \%$ of all elbow fractures. ${ }^{[48]}$

\section{Indications for surgery}

Davies produced a classification that can be easily applied clinically. It divides the fractures in extra-articular, predominantly intra-articular or predominantly articular types (Fig. 7). ${ }^{[49]} \mathrm{CT}$ scan can be made in complex fractures to assess the type of fracture, and the number and orientation of the fragments.

\section{Pearls and pitfalls}

- A posterior approach is mostly used; depending on the fracture, a posterior triceps-on approach or an olecranon osteotomy can be preferred (Fig. 7).

- Always identify the ulnar nerve; transposition is not needed in general.

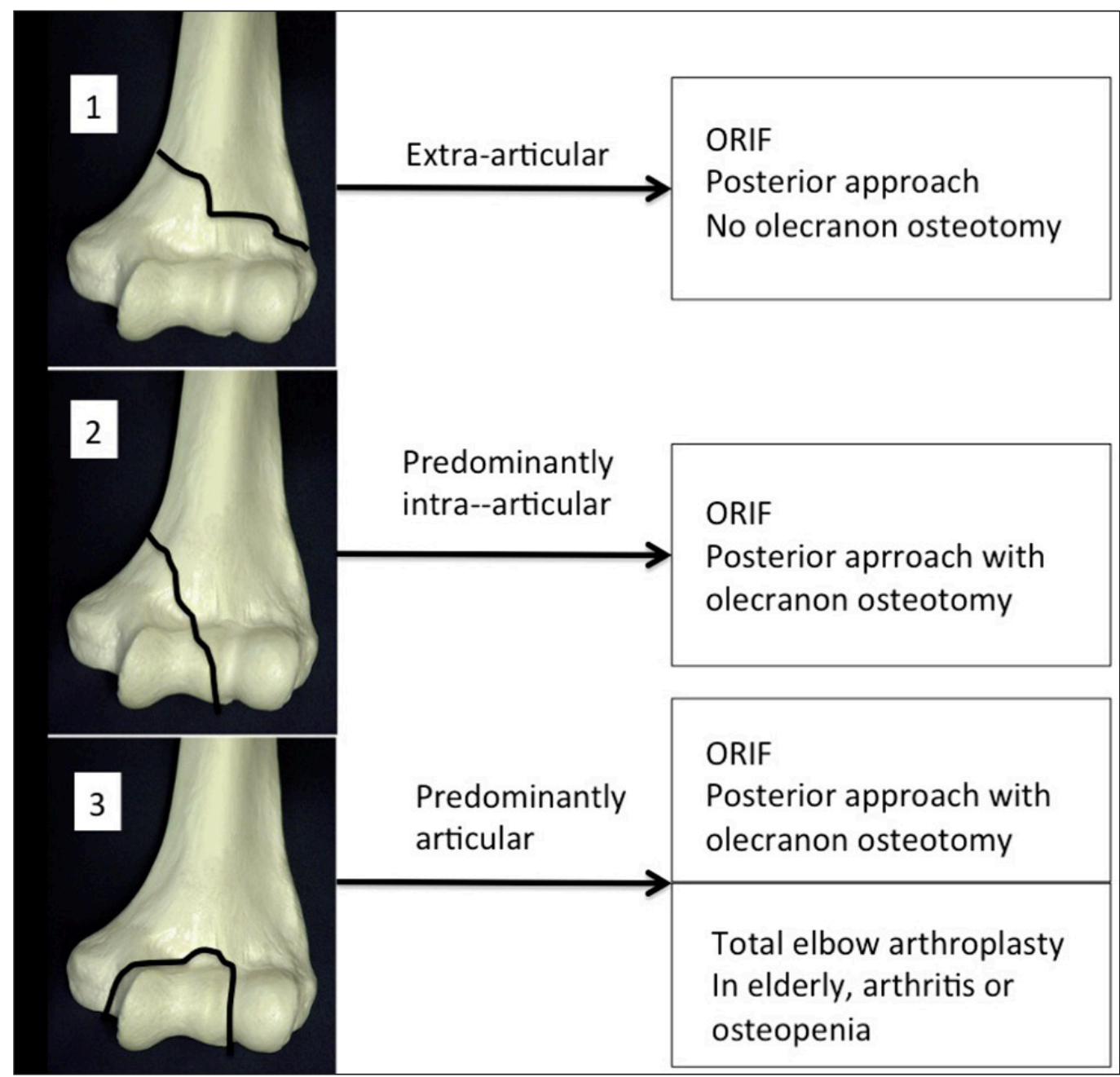

Şekil 7. Distal humerus kırıklarında Davies sınıflaması ve buna göre yaklaşım algoritması.
Figure 7. Davies classification for fractures of the distal humerus including management algorithm. 
- Olekranon osteotomisi yaparken Chevron tipi ya da ucu distali gösterecek şekilde $V$ osteotomisi yapılması, osteotominin rotasyonel stabilitesini arttırır.

- Osteotomi öncesi kemikte tespit amaçlı delik açmak, sonrasında anatomik redüksiyonu çok daha kolay hale getirir.

- ilk olarak birbirine tam uyan eklem içi parçaları tespit ederek başlayıp, ardından onlara göre redüksiyon sağlanır.

- Önceden bükülmüş plaklar şablon olarak kullanılıp, kırık redüksiyonu bunlara göre yapılabilir.

- Daha distaldeki eklem dışı kırıklar, çift plak tekniği kullanılarak tespit edilmelidir.

- Çift plaklama tekniği paralel ya da 90-90 plaklama olabilir. Paralel plaklama daha çok yumuşak doku diseksiyonu gerektirse de, bir tekniğin diğerine üstünlüğü ile ilgili klinik kanıt yoktur.

- ilk olarak eklem içi yüzey redükte edilmeye başlanmalı, geçici tespit için K-telleri kullanılmalı ve radius başı ile proksimal ulna şablon olarak kullanılmalıdır.

- Humerusun anterior eklem parçası fonksiyonel bir eklem için en önemli kısımdır.

- Eklemleşmenin stabilitesi için troklea mediyali ile birlikte ya trokleanın laterali ya da kapitellum mevcut olmalıdır.

- Eğer ameliyat öncesi kırığın rekonstrükte edilemeyeceğine karar verildiyse, hemiartroplasti ya da total eklem replasmanı yapılması değerlendirilmelidir.

\section{Sonuçlar}

\section{Eklem dışı}

Sarmiento ve arkadaşları askı alçısı ve sonrasında fonksiyonel breysleme ile iyi sonuçlar bildirmişlerdir; ancak, bu sonuçlar diğer merkezlerde elde edilememektedir. ${ }^{[50,51]}$ Son çalışmalar anatomik rekonstrüksiyon ve içten tespitin daha iyi sonuçlar verdiğini göstermiştir. ${ }^{[52]}$ Cerrahi dışı tedavi, ameliyat edilemeyecek durumdaki hastalarda uygulanmalıdır.

\section{Kısmen eklem içi kırıklar}

Kaynamamaların çoğunluğu (\%75'e kadar) yetersiz ilk tespite bağlıdır. ${ }^{[33]}$ Cerrahi dışı tedavi sonuçları açık redüksiyon, içten tespit ve erken hareketle karşılaştırıldığında kötüdür ve ameliyata uygun olmayan hastalarda uygulanmalıdır. ${ }^{[54]}$
- When fractures extend more proximal, the radial nerve must also be identified and protected during the procedure.

- The radial nerve crosses the posterior cortex of the humerus about $10 \mathrm{~cm}$ proximal to the lateral epicondyle.

- When using an olecranon osteotomy, we advise to make a Chevron or V-shaped osteotomy to increase the rotational stability through the non-articulating part of the olecranon with the $\mathrm{V}$ pointing distally.

- Pre-drilling holes to fix the osteotomy prior to performing makes anatomical reconstruction much easier.

- Start reconstructing intra-articular fractures by fixating fragments that are clearly fit together and build up from there.

- Precontoured plates can be used as a template on which the fracture can be reduced.

- The more distal extra-articular fractures should be stabilized using a double plating technique.

- Double plating can be parallel to or with the 9090 technique. There is no clinical evidence that one technique is superior to the other; parallel plating necessitates more soft tissue dissection.

- Start reducing the intra-articular surface first; use K-wires for temporary fixation, and use the radial head and proximal ulna as a template.

- The anterior articular part of the humerus is the most important part for a functional joint.

- Stability of the articulation requires the presence of the medial trochlea in combination with either the lateral half of the trochlea or the capitellum.

- If a preoperative decision is made that the fracture is not reconstructable, a hemiarthoplasty or a total joint replacement should be considered.

\section{Results}

\section{Extra-articular}

Sarmiento et al. reported good results of non-operative treatment using a hanging cast followed by functional bracing; these results however could not be reproduced in other institutes. ${ }^{[50,51]}$ Recent studies show that anatomical reconstruction and internal fixation produces better outcomes. ${ }^{[52]}$ Non-operative treatment should be reserved for patients unfit for surgery.

\section{Predominantly intra-articular fractures}

The majority (up to $75 \%$ ) of non-unions are due to inadequate primary fracture fixation. ${ }^{[53]}$ Non-operative 


\section{Eklem içi kırıklar}

Ring ve arkadaşları açık redüksiyon ve içten tespitle tedavi ettikleri 21 eklem içi distal humerus kırıklı hastanın 16'sında iyi ve mükemmel sonuç elde etmişlerdir. Hastaların ortalama takip süresi 40 ay, ulnohumeral eklemdeki hareket genişliği $96^{\circ}$ 'dir. On hasta daha sonra ikinci cerrahiye ihtiyaç duymuştur (altı kontraktür gevşetmesi, iki ulnar sinir dekompresyonu, bir tespit revizyonu ve bir implant çıkartılması). [55] Dubberley ve arkadaşları, 28 hastada ortalama 56 aylık takiplerinde fonksiyonel sonuçlarını bildirmişlerdir. Ortalama Mayo performansı $91 \pm 11$, ortalama hareket genişliği $19-138^{\circ}$ 'dir. Parçalı kırığı olan iki hastada kaynamama görülmüş ve total protez yapılmıştır. ${ }^{[56]}$

\section{Komplikasyonlar}

Ulnar ve eğer kırık daha proksimalde ise radyal siniri bulup korumak, yaralanma riskini en aza indirmektedir. Cerrah, ameliyat esnasında herhangi bir sinir hasarı olmadığından emin olursa, ameliyat sonrası dönemdeki her türlü duyusal ve/veya motor disfonksiyon nöropraksi olarak değerlendirilir ve $2-3$ ayda düzelmesi beklenir. Dirseğin hızla (pasif) mobilizasyonu, ameliyat sonrası sertliği engellemek için önemlidir. Bu nedenle, ana hedef stabil tespit ile uyumlu eklem yüzü elde etmek ve erken eklem hareketine başlamaktır. Daha önce de söz edildiği gibi, Ali ve arkadaşları kaynamamaların \%75'inin nedeni olarak sadece K-telleri, vidalar ya da yetersiz plaklarla yapılan uygunsuz tespitleri göstermişlerdir. ${ }^{[33]}$ Hamid ve arkadaşları, heterotopik ossifikasyonun tedavisinde acil ameliyat sonrası radyoterapiye ihtiyaç olmadığını, bu yöntemin kaynamama oranını arttırdığını göstermişlerdir. ${ }^{[57]}$ treatment gives poor outcome when compared to ORIF and early mobilization and should be reserved for patients unfit for surgery. ${ }^{[54]}$

\section{Articular fractures}

Good to excellent results were presented by Ring et al. in 16 of 21 patients who had ORIF of articular fractures of the distal humerus at a mean follow-up of 40 months with an average arc of movement of $96^{\circ}$ at the ulnohumeral joint. Ten patients required a second operation (six contracture releases, two for ulnar nerve decompressions, one needed revision of fixation, and one had removal of metal work). ${ }^{[5]}$ Dubberley et al. reported functional outcomes in 28 patients with a mean follow-up of 56 months. The average Mayo performance index was $91 \pm 11$ with a mean range of motion of $19-138^{\circ}$. Two patients with comminution had non-union requiring total elbow arthroplasty. ${ }^{[56]}$

\section{Complications}

Finding and protecting the ulnar and, if the fracture is more proximal, the radial nerve during surgery minimizes the risk of damaging these important structures. Provided the surgeon is confident that the neurological anatomy has not been damaged during the surgical procedure, any postoperative sensory and/or motor dysfunction is likely to be a neuropraxia, which will normally recover within 2-3 months. Immediate (passive) mobilization of the elbow is the most important issue in preventing postoperative stiffness. It is for this reason that the primary objective remains as the restoration of a congruous joint surface with definitive stable fixation that allows early progression to motion. As mentioned before Ali et al. reported that $75 \%$ of the non-unions had a sub-optimal primary treatment with only K-wires, screws or inadequate plates. ${ }^{[53]} \mathrm{Hamid}$ et al., in a study terminated prior to completion due to a higher rate of non-unions following radiotherapy, showed that there is no role for immediate postoperative radiotherapy for prophylaxis against heterotopic ossification. ${ }^{[57]}$

\section{KAYNAKLAR / REFERENCES}

1. van Riet RP, Van Glabbeek F, Morrey BF. Radial head fracture. In: Morrey BF, editor. The elbow and its disorders. 4th ed. Philadelphia, PA: Saunders Elsevier; 2009:359-81.

2. Kaas L, van Riet RP, Vroemen JP, Eygendaal D. The incidence of associated fractures of the upper limb in fractures of the radial head. Strategies Trauma Limb Reconstr 2008;3(2):714. CrossRef

3. van Riet RP, Morrey BF, O'Driscoll SW, Van Glabbeek F. Associated injuries complicating radial head fractures: a demographic study. Clin Orthop Relat Res 2005;441:351-5.
4. Mason ML. Some observations on fractures of the head of the radius with a review of hundred cases. $\mathrm{Br} J$ Surg 1954;42(172):123-32

5. Johnston GW. A follow-up of one hundred cases of fractures of the head of the radius with a review of the literature. Ulster Med J 1962;31:51-6.

6. van Riet RP, Morrey BF. Documentation of associated injuries occurring with radial head fracture. Clin Orthop Relat Res 2008;466(1):130-4. CrossRef 
7. Guitton TG, van der Werf HJ, Ring D. Quantitative threedimensional computed tomography measurement of radial head fractures. J Shoulder Elbow Surg 2010;19(7):973-7. CrossRef

8. Liow RY, Cregan A, Nanda R, Montgomery RJ. Early mobilisation for minimally displaced radial head fractures is desirable: a prospective randomised study of two protocols. Injury 2002;33:801-6.

9. Herbertsson P, Josefsson PO, Hasserius R, Karlsson C, Besjakov J, Karlsson MK. Displaced Mason type I fractures of the radial head and neck in adults: a fifteen- to thirty-threeyear follow-up study. J Shoulder Elbow Surg 2005;14(1):73-7.

10. Burkhart KJ, NowakTE, Appelmann P, Sternstein W, Rommens PM, Mueller LP. Screw fixation of radial head fractures: compression screw versus lag screw--a biomechanical comparison. Injury 2010;41(10):1015-9. CrossRef

11. Ikeda M, Sugiyama K, Kang C, Takagaki T, Oka Y. Comminuted fractures of the radial head: comparison of resection and internal fixation. Surgical technique. J Bone Joint Surg Am 2006;88 Suppl 1 Pt 1:11-23.

12. Ring D, Quintero J, Jupiter JB. Open reduction and internal fixation of fractures of the radial head. J Bone Joint Surg Am 2002;84-A(10):1811-5.

13. Morrey BF. Prosthetic radial head replacement. In: Morrey BF, editor. The elbow and its disorders. 4th ed. Philadelphia, PA: Saunders Elsevier; 2009. p.381-8.

14. Brinkman JM, Rahusen FT, de Vos MJ, Eygendaal D. Treatment of sequelae of radial head fractures with a bipolar radial head prosthesis: good outcome after 1-4 years follow-up in 11 patients. Acta Orthop 2005;76(6):867-72.

15. Shore BJ, Mozzon JB, MacDermid JC, Faber KJ King GJ. Chronic posttraumatic elbow disorders treated with metallic radial head arthroplasty. J Bone Joint Surg Am 2008;90(2):271-80. CrossRef

16. Antuña SA, Sánchez-Márquez JM, Barco R. Long-term results of radial head resection following isolated radial head fractures in patients younger than forty years old. J Bone Joint Surg Am 2010;92(3):558-66. CrossRef

17. Boulas HJ, Morrey BF. Biomechanical evaluation of the elbow following radial head fracture. Comparison of open reduction and internal fixation vs. excision, silastic replacement, and non-operative management. Chir Main 1998;17(4):314-20.

18. Unsworth-White J, Koka R, Churchill M, D'Arcy JC, James SE. The non-operative management of radial head fractures: a randomized trial of three treatments. Injury 1994;25(3):165-7.

19. Wright JG, Einhorn TA, Heckman JD. Grades of recommendation. J Bone Joint Surg Am 2005;87(9):1909-10.

20. Akesson T, Herbertsson P, Josefsson PO, Hasserius R, Besjakov J, Karlsson MK. Primary nonoperative treatment of moderately displaced two-part fractures of the radial head. J Bone Joint Surg Am 2006;88(9):1909-14.

21. Struijs PA, Smit G, Steller EP. Radial head fractures: effectiveness of conservative treatment versus surgical intervention. A systematic review. Arch Orthop Trauma Surg 2007;127(2):125-30.

22. Ruan HJ, Fan CY, Liu JJ, Zeng BF. A comparative study of internal fixation and prosthesis replacement for radial head fractures of Mason type III. Int Orthop 2009;33(1):249-53.

23. Smets S, Govaers K, Jansen N, Van Riet R, Schaap M, Van Glabbeek $F$. The floating radial head prosthesis for comminuted radial head fractures: a multicentric study. Acta Orthop Belg 2000;66(4):353-8.
24. Herbertsson $P$, Josefsson $P O$, Hasserius R, Karlsson C, Besjakov J, Karlsson M; Long-Term Follow-Up Study. Uncomplicated Mason type-II and III fractures of the radial head and neck in adults. A long-term follow-up study. J Bone Joint Surg Am 2004;86-A(3):569-74.

25. Michels F, Pouliart N, Handelberg F. Arthroscopic management of Mason type 2 radial head fractures. Knee Surg Sports Traumatol Arthrosc 2007;15(10):1244-50.

26. Van Glabbeek F, Van Riet R, Verstreken J. Current concepts in the treatment of radial head fractures in the adult: a clinical and biomechanical approach. Acta Orthop Belg 2001;67(5):430-41.

27. An K-N, Zobitz ME, Morrey BF. Biomechanics of the elbow. In: Morrey BF, Sanchez-Sotelo J, ed. The elbow and its disorders, Philadelphia, PA: Saunders Elsevier; 2009. p.39-66.

28. Adams JE, Steinmann SP. Fractures of the olecranon. In: Morrey BF, Sanchez-Sotelo J, editors. The elbow and its disorders. Philadelphia, PA: Saunders Elsevier; 2009. p.389-400.

29. Keener JD, Chafik D, Kim HM, Galatz LM, Yamaguchi K. Insertional anatomy of the triceps brachii tendon. J Shoulder Elbow Surg 2010;19(3):399-405. CrossRef

30. Romero JM, Miran A, Jensen $\mathrm{CH}$. Complications and reoperation rate after tension-band wiring of olecranon fractures. J Orthop Sci 2000;5(4):318-20.

31. Wolfgang G, Burke F, Bush D, Parenti J, Perry J, LaFollette B, Lillmars S. Surgical treatment of displaced olecranon fractures by tension band wiring technique. Clin Orthop Relat Res 1987;(224):192-204.

32. Johnson RP, Roetker A, Schwab JP. Olecranon fractures treated with $\mathrm{AO}$ screw and tension bands. Orthopedics 1986;9(1):66-8.

33. Simpson NS, Goodman LA, Jupiter JB. Contoured LCDC plating of the proximal ulna. Injury 1996;27(6):411-7.

34. Bailey CS, MacDermid J, Patterson SD, King GJ. Outcome of plate fixation of olecranon fractures. J Orthop Trauma 2001;15(8):542-8.

35. Anderson ML, Larson AN, Merten SM, Steinmann SP. Congruent elbow plate fixation of olecranon fractures. J Orthop Trauma 2007;21(6):386-93.

36. Ring D, Jupiter JB, Saunders RW, Mast J, Simpson NS. Transolecranon fracture-dislocation of the elbow. J Orthop Trauma 1997;11(8):545-50.

37. Lindenhovius AL, Brouwer KM, Doornberg JN, Ring DC, Kloen P. Long-term outcome of operatively treated fracture-dislocations of the olecranon. J Orthop Trauma 2008;22(5):325-31. CrossRef

38. Kloen P, Buijze GA. Treatment of proximal ulna and olecranon fractures by dorsal plating. Oper Orthop Traumatol 2009;21(6):571-85. CrossRef

39. Erpelding JM, Mailander A, High R, Mormino MA, Fehringer EV. Outcomes following distal humeral fracture fixation with an extensor mechanism-on approach. J Bone Joint Surg Am 2012;94(6):548-53. CrossRef

40. Ates $\mathrm{Y}$, Atlihan D, Yildirim $\mathrm{H}$. Current concepts in the treatment of fractures of the radial head, the olecranon and the coronoid. J Bone Joint Surg Am 1996;78(6):969.

41. Coonrad RW, Morrey BF. Management of olecranon fractures and nonunions. In: Morrey BF, editor. The elbow: master techniques in orthopaedic surgery, Philadelphia, PA: Lippincott Williams \& Wilkins; 2002.

42. Bado JL. The Monteggia lesion. Clin Orthop Relat Res 1967;50:71-86 
43. Hume MC, Wiss DA. Olecranon fractures. A clinical and radiographic comparison of tension band wiring and plate fixation. Clin Orthop Relat Res 1992;(285):229-35.

44. Horne JG, Tanzer TL. Olecranon fractures: a review of 100 cases. J Trauma 1981;21(6):469-72.

45. Ishigaki $\mathrm{N}$, Uchiyama $\mathrm{S}$, Nakagawa $\mathrm{H}$, Kamimura $\mathrm{M}$, Miyasaka T. Ulnar nerve palsy at the elbow after surgical treatment for fractures of the olecranon. J Shoulder Elbow Surg 2004;13(1):60-5.

46. van Kloot JF. Results of treatment of fractures of the olecranon. Arch Chir Neerl 1964;16(4):237-49.

47. Robinson CM, Hill RM, Jacobs N, Dall G, CourtBrown CM. Adult distal humeral metaphyseal fractures: epidemiology and results of treatment. J Orthop Trauma 2003;17(1):38-47.

48. Korner J, Lill H, Müller LP, Rommens PM, Schneider E, Linke $B$. The LCP-concept in the operative treatment of distal humerus fractures--biological, biomechanical and surgical aspects. Injury 2003;34 Suppl 2:B20-30.

49. Davies MB, Stanley D. A clinically applicable fracture classification for distal humeral fractures. J Shoulder Elbow Surg 2006;15(5):602-8.

50. Sarmiento A, Horowitch A, Aboulafia A, Vangsness CT Jr. Functional bracing for comminuted extra-articular fractures of the distal third of the humerus. J Bone Joint Surg $\mathrm{Br}$ 1990;72(2):283-7.
51. Aitken GK, Rorabeck $\mathrm{CH}$. Distal humeral fractures in the adult. Clin Orthop Relat Res 1986;(207):191-7.

52. Jawa A, McCarty P, Doornberg J, Harris M, Ring D. Extraarticular distal-third diaphyseal fractures of the humerus. A comparison of functional bracing and plate fixation. J Bone Joint Surg Am 2006;88(11):2343-7.

53. Ali A, Douglas H, Stanley D. Revision surgery for non-union after early failure of fixation of fractures of the distal humerus. J Bone Joint Surg Br 2005;87(8):1107-10.

54. Papaioannou N, Babis GC, Kalavritinos J, Pantazopoulos T. Operative treatment of type $C$ intra-articular fractures of the distal humerus: the role of stability achieved at surgery on final outcome. Injury 1995;26(3):169-73.

55. Ring D, Jupiter JB, Gulotta L. Articular fractures of the distal part of the humerus. J Bone Joint Surg Am 2003;85-A(2):232-8.

56. Dubberley JH, Faber KJ, Macdermid JC, Patterson SD, King $G$. Outcome after open reduction and internal fixation of capitellar and trochlear fractures. J Bone Joint Surg Am 2006;88(1):46-54.

57. Hamid N, Ashraf N, Bosse MJ, Connor PM, Kellam JF, Sims $\mathrm{SH}$, Stull DE, Jeray KJ, Hymes RA, Lowe TJ. Radiation therapy for heterotopic ossification prophylaxis acutely after elbow trauma: a prospective randomized study. J Bone Joint Surg Am 2010;92(11):2032-8. CrossRef 